\title{
Reduction Defect in Sewing Work Stations by Integrating OTSM-TRIZ and FMEA
}

\author{
M. Hanifuddin Hakim ${ }^{1}$ and Moses Laksono Singgih ${ }^{1}$
}

\begin{abstract}
The problems that occur in PT Sepatu are still many defect products. To improve the quality and reduce the number of defects is to make improvements to the flow of the process by using the DMAI stages. In the Define stage, the determination of the selected critical defect is needle fracture, jump stitch, loose stitch, Upper symmetry, and Upper wrinkling. In the Measure phase, DPMO measurements were carried out at 4028 units and a sigma level of 4.1. In the Analyze stage, analyze complex problems that cause defects in the sewing department using Network of Problem (NoP). The output of Nop in the form of partial solution (Ps) and sub problem (Pb) becomes the FMEA input, which will then be analyzed and measured in the value of the RPN. The potential Failure Mode (s) with the highest RPN score in the FMEA table will be a priority and become the initial input to the OTSM-TRIZ stage procedure. In the Improve phase using 40 selected inventory principles the repair solution performs cleaning and checking the position of the rotary-yarn tip at the start of each shift, gives a sign sticker on the tension ring, makes a tool to check bent needles, conducts employee training and employee skill mapping. From the results of the implementation of recommendations, improvements to the estimated reduction defect of 705 pairs of shoes with sigma 4.3 level.
\end{abstract}

Keywords-FMEA, Quality, NoP, OTSM-TRIZ, Six Sigma.

\section{INTRODUCTION}

The footwear industry in Indonesia is increasingly experiencing a promising increase. Indonesia is the sixth largest exporter of footwear products in the world. PT Sepatu is a company that focuses on the footwear manufacturing industry. The majority of the products produced are sport shoes. The marketing of these products has penetrated foreign markets, including Korea, China and Japan. The type of fulfillment of PT Sepatu's production demand uses a Make to Order system with mass customization production. The marketing of these products has penetrated foreign markets, including Korea, China and Japan. While domestic marketing is mostly consumers from Government Agencies. Every year PT Sepatu is able to produce as many as $\pm 2,500,000$ pairs of shoes. To meet this huge demand, PT Sepatu employs 2,200 employees with the majority of them being female employees.

The process of making shoes starts from the cutting stage. The cutting stage is the process of cutting shoes from leather or fabric according to the specified pattern. The

\footnotetext{
${ }^{1}$ M. Hanifuddin Hakim and Moses Laksono Singgih are with Department of Industrial Engineering, Institut Teknologi Sepuluh Nopember, Surabaya, Indonesia. Email: moseslsinggih@ie.its.ac.id.
}

next stage is the screen printing process. This process is used to print ink on the surface of the material that has gone through cutting. The next stage is welding shop (emboss). Emboss is a process of forming on the surface of the material that has been screened. The next stage is sewing. This process is a combination of shoe parts using a sewing machine. This department is designed using a line system. Each line consists of \pm 25 people, depending on what type of shoes are produced. Every employee gets a different job according to the division of labor. Each line has a target of being able to produce $40-45$ pairs of shoes in one hour or 1 pair of shoes in 80-90 seconds. The next stage is assembly. This process is the upper assembly (the upper part of the shoe) and the bottom (the bottom of the shoe / sole) to become a complete shoe.

The average defect product that must be disposed of reaches $2 \%$ of total production. Even though the standard defect set by the company must not exceed $1 \%$ of total production. While the average rework product reaches $15 \%$ of the total production of all departments. The most rework activity is in the sewing department with a percentage of $30 \%$ of total production. From the brainstorming process of researchers and the company's quality control, many defect products are caused by the quality of the sewing process that is not in accordance with the standard. Therefore, in this study, researchers will focus on reducing defects by focusing on the sewing department.

Quality is conformance to requirement, which is in accordance with what is hinted or standardized [1]. The company must really understand what consumers need for a product to be produced [2]. A product can be said to be of quality if the product meets customer satisfaction [3]. Consumers have tastes or expectations on a product that is always changing so that the quality of the product must also be adapted to these changes [4]. The compatibility of product use (fitness for use) must be considered to meet customer needs and satisfaction [5]. Quality is one of the guarantees given and must be fulfilled by the company to customers, because the quality of a product is one of the important criteria that is considered by customers in choosing products [6]. The method used to solve the problem is the high level of variation and defect, one that is often used is Six Sigma. Six Sigma is a structured methodology to improve processes that are focused on reducing process variances while reducing defects [7]. 


\section{LITERATURE RIVIEW}

In the improve phase in the previous Six Sigma studies, many factors influencing the quality of processes and products were obtained from analysis with Fishbone, FMEA, Brainstorming and similar tools. These tools are able to detect problems specifically, but these tools are unable to find the right solution directly. According to many professionals, the TRIZ method is the only systematic innovation tool available [8]. Altshuller analyzed about 400,000 descriptions of inventions from various engineering fields to reveal objective laws (trends) in the evolution of engineering systems [9]. TRIZ translates specific problems into abstract problems or problem models and then to abstract solutions or solution models [10]. One other advantage of TRIZ, this method offers tools to deal with contradictions [11].

Combining the concepts of DFMA and TRIZ. Design for manufacture (DFMA) provides design guidelines to consider manufacturing capability issues beyond product performance [12]. While other researchers [13] with the same scope, namely design and cost reduction, conducting research into the integration of DFD and TRIZ. Design for Disassembly (DFD) is a design guideline considering the ease of dismantling part products more easily at the end of their life. A systematic integration between QFD and TRIZ [14] was first carried out with the aim of QFD to convert customer requirements into quality engineering parameters. Then QFD reveals a negative correlation in the quality parameter pairs, which can be seen as a TRIZ contradiction. Then use TRIZ to resolve this contradiction. Research with a similar approach also exploits QFD to clarify design tasks and TRIZ to find the right solution in developing new valve designs. In addition, he also suggested using these tools together with the Life Cycle Assessment (LCA) to harmonize Voice of the Customer, environmental issues and related products. [15]. No different, [16] using the House of Quality QFD model to show conflicting problems, which are solved by TRIZ. Other researchers [17], [18] proposed a TRIZ-based methodology integrated into QFD. The integration of QFD, AHP, FMEA and TRIZ is proposed to optimize design parameters that can satisfy consumers.

The integration of FMEA and TRIZ aims to improve the quality of plastic packaging products. FMEA is used to determine which factors have the greatest potential cause of failure based on the FMEA RPN Value. TRIZ is used to provide guidance on problem solving from the factors that cause the highest failure [19]. Whereas [20] compared the classic TRIZ with OTSM-TRIZ, which was applied in a balloon design case study. The problem is very complex, if the analysis is done with TRIZ Classic, none of the problems in the initial list can be defined as small problems, and therefore extracting directly a contradiction will not be possible. OTSM-TRIZ instead, with a typical network approach, allows users to enter the solutions generated at each step of the problem solving process in NoP.

The approach to using OTSM-TRIZ is carried out with the aim of guaranteeing and obtaining benefits in resolving complex and interconnected problems. This OTSM-TRIZ method appears to fill the shortcomings of classic TRIZ. In classic TRIZ it does not accommodate complex and interconnected problems. So from that the use of the OTSM-TRIZ method is used to overcome problems that are complex with Network of Problem (NoP). NoP is used to parse the main problems, namely defects into sub problems and partial solutions. The more complex the problem, the more sub-problems and partial solutions that appear. The probability of sub problem one is connected with another sub problem and partial solution one is connected with the other partial solution [20].

However, in OTSM-TRIZ, out of the many subproblems that have arisen, there is no specific sub-problem determination which should be chosen. If we have to solve all the sub problems that arise, of course it will require a lot of money and effort. Need tools that are used to prioritize which sub-problems to choose. The FMEA tool was chosen to determine which problems resulted from NoP based on sub-problems which had the greatest potential risk of failure. So that the general solution produced by the OTSM-TRIZ method can be more reliable in facing failure.

\section{METHOD}

The research methodology is based on a simple problemsolving methodology - DMAI, which stands for Define, Measure, Analyze, and Improve. The development of the problem solving model flow enters the define stage by determining the objectives and required company data collection, making the operation process chart (OPC) to find out the details of the production flow, getting customer requirements which are translated into critical to quality (CTQ) to become the initial data will be processed in accordance with quality assurance procedures in the company, followed by determining priority processes, identifying critical defects based on CTQ that occur in critical processes, and analyzing based on NoP to solve complex problems so as to find sub-problems (sp) and partial solutions (ps) in critical process, then integrate with the FMEA method to find sub-problems which have the greatest potential cause of failure. In the improve phase, integration with the OTSM-TRIZ method is carried out to get recommendations for suitable repairs so as to improve the quality of shoe products. Then carried out an analysis and discussion of the application of the methods that have been made. The final stage of the research flow is closed by giving conclusions and suggestions. 


\section{RESUlT AND DISCUSSION}

\section{A. Define}

The main processes at PT SEPATU are cutting, screen printing, emboss, outsole, insole, sewing, assembly and packing. The focus of this research was carried out in the sewing department. The sewing process is a production part that combines the patterns of raw materials that have been cut into the upper (upper) part of the shoe. To find out the desirable characteristics of consumers used critical to quality (CTQ). The identification of CTQ is shown in table 1.

TABLE 1.

CTQ OF THE SEWING DEPARTMENT

\begin{tabular}{|c|c|c|c|}
\hline Product & $\begin{array}{l}\text { Process } \\
\text { Type }\end{array}$ & CTQ & Descricpion \\
\hline \multirow{6}{*}{$\begin{array}{l}\text { Shoe } \\
\text { Products }\end{array}$} & \multirow{6}{*}{ Sewing } & $\begin{array}{l}\text { Needle } \\
\text { fracture }\end{array}$ & $\begin{array}{l}\text { There are no broken needles } \\
\text { entering the Upper }\end{array}$ \\
\hline & & $\begin{array}{l}\text { Stitch } \\
\text { step }\end{array}$ & $\begin{array}{l}\text { - Step sewing every } 1 \text { inch }=8-9 \\
\text { steps of the same stitch } \\
\text { - Stitch distance with Upper edge } \\
1,5-2 \mathrm{~mm}\end{array}$ \\
\hline & & Upper & $\begin{array}{l}\text { - Sewing Toe Cap must be } \\
\text { symmetry and should not be } \\
\text { tilted }\end{array}$ \\
\hline & & Symmetry & $\begin{array}{l}\text { - Sewing Back Counter must be } \\
\text { symmetry and should not be } \\
\text { tilted }\end{array}$ \\
\hline & & $\begin{array}{l}\text { Upper } \\
\text { wrinkles }\end{array}$ & Upper surface does not wrinkle \\
\hline & & Jump & $\begin{array}{l}\text { Stitches according to the pattern, } \\
\text { do not jump. }\end{array}$ \\
\hline
\end{tabular}

The process of making shoe products especially in the sewing department still has defects. With this defect will automatically reduce the level of product quality while affecting customer needs and satisfaction. The relationship with CTQ is a defect that occurs due to the key quality characteristics of a product that does not meet the standards set by the CTQ itself.

Identification of the types of defects that affect the quality of shoes in the sewing process. After conducting interviews and brainstorming with people who are experts in the field of company quality, there is a link between the production process that has been described in OPC with the occurrence of product defects. The type of product defect in shoes in the sewing department consists of 5 types, namely needle fracture, jump stitch, loose stitch, upper asymmetry, upper wrinkled. Details of the number of defects are shown in Table 2.

\section{B. Measure}

The current production process is still low because the DPMO value is still high at 4028 which means that from one million opportunities there are still 4028 possibilities that the production process will produce defects. The DPMO value is then converted into a sigma level and a value of 4.1 sigma is obtained. This value can still be categorized as good for industries in Indonesia because the industry average in Indonesia still ranges in level 3 sigma. However, the sigma level of the company is still unable to compete in the world class with quality control at level 6 sigma. When viewed from the point of view of a Six Sigma project, the value is still categorized as low because the purpose of a Six Sigma project is to obtain process capability at the level of 6 sigma control so that it can produce a possible 3.4 failure per million opportunities. Whereas from the calculation of process capability it can be seen that the value of $\mathrm{Cp}=0.89$ which shows the overall process capability is still low because the value is at $\mathrm{Cp}$ $<1.00$.

TABLE 2. NUMBER OF DEFECTS

\begin{tabular}{clccc}
\hline \hline No & Defect type & Total & $\%$ & Kum \\
\hline 1 & No symmetry & 563 & $28 \%$ & $28 \%$ \\
2 & Sagging Seams & 502 & $25 \%$ & $53 \%$ \\
3 & Skip stitches & 362 & $18 \%$ & $71 \%$ \\
4 & Needle Fault & 301 & $15 \%$ & $86 \%$ \\
5 & Upper wrinkled & 281 & $14 \%$ & $100 \%$ \\
& Total & 2009 & & \\
\hline \hline
\end{tabular}

C. Analyze

1) Network Of Problem (NoP)

NoP making is carried out with the aim to unravel the complex problems that occur in the sewing department. Problem is focused on improving quality by reducing the number of defects. NoP is part of OTSM-TRIZ which is used to describe multilevel contradictions. The process of making NoP through the process of filling out questionnaires and brainstorming with companies that have experience and understand the process well. The results of making NoP are shown in figure 1 and the explanation in Table 3 .

Making NoP starting from the main problem to be examined is defect, symbolized by problem $1(\mathrm{~Pb} 1)$. Furthermore, from the CTQ that has been made previously, there were 5 types of defects, namely needle fracture, loose stitch, jump stitch, asymmetrical upper, and upper wrinkles which were symbolically represented by PB 2, PB 3, PB 4, $\mathrm{PB} 5$, and $\mathrm{Pb} 6$.

\section{2) Failure Mode and Effect Analysis (FMEA)}

After parsing complex problems using the network of problems, the next step is to make FMEA which aims to analyze potential process failures and evaluate these failures. FMEA is used to determine the failure that gives the biggest contribution to each critical defect so that it becomes a priority to be given recommendations for improvement. The FMEA table is created and filled through the process of filling out questionnaires and brainstorming with experienced companies, in this case based on assessments from maintenance experts, production experts, and Quality Control (QC) experts in the 
sewing department. The results of making FMEA are shown in Table 4.

From the calculation of FMEA RPN value can be calculated Defect jump jump has the highest RPN value of 448. This type of defect is caused by the causes of wear failure of the shuttle hock napless. Defect Saggy stitch with RPN 336 value. This type of defect is caused by a factor causing the failure to set tension threads that often change. Defect fracture of the needle with RPN 315 value. This type of defect is caused by the failure factor of the bent sewing needle. Upper Defect is not symmetrical with RPN 288 value. This type of defect is caused by factors causing employee skill failure that are not in accordance with the standard. Upper defect wrinkled with RPN 252. As with Upper symmetry defect, this type of defect is caused by factors causing employee skill failure that are not in accordance with the standard.

TABLE 3.

DESCRIPTION OF CHART NOP

\begin{tabular}{|c|c|c|c|}
\hline $\mathrm{Pb} / \mathrm{Ps}$ & Description & $\mathrm{Pb} / \mathrm{Ps}$ & Description \\
\hline $\mathrm{Pb} 1$ & Defect & Ps 23 & Tool bolt \\
\hline $\mathrm{Pb} 2$ & Needle Fault & $\mathrm{Pb} 24$ & Equipment costs \\
\hline $\mathrm{Pb} 3$ & Sagging Seams & Ps 25 & Needles have been used \\
\hline $\mathrm{Pb} 4$ & Stitches Jump & $\mathrm{Pb} 26$ & Setup time \\
\hline $\mathrm{Pb} 5$ & Upper No Symmetry & $\mathrm{Pb} 27$ & Thick glue \\
\hline $\mathrm{Pb} 6$ & Upper Crimped & Ps 28 & $\begin{array}{l}\text { Supervisors are more } \\
\text { stringent }\end{array}$ \\
\hline $\mathrm{Pb} 7$ & Crooked Needle & $\mathrm{Pb} 29$ & $\begin{array}{l}\text { The upper and lower } \\
\text { mechine settings change }\end{array}$ \\
\hline $\mathrm{Pb} 8$ & thick material & $\mathrm{Pb} 30$ & Shuttle hock napples \\
\hline Ps 9 & Decrease in speed & Ps 31 & Shuttle hock sharpened \\
\hline $\mathrm{Pb} 10$ & Line not balance & $\mathrm{Pb} 32$ & Fulfillment of targets \\
\hline Ps 11 & Sharing the workload & $\mathrm{Pb} 33$ & Hurry \\
\hline Ps 12 & New needle check & Ps 34 & Buffer storage \\
\hline $\mathrm{Pb} 13$ & Difficulty checking & $\mathrm{Pb} 35$ & WIP costs \\
\hline Ps 14 & Create a tool & Ps 36 & $\begin{array}{l}\text { Buffers are only at a } \\
\text { certain point }\end{array}$ \\
\hline $\mathrm{Pb} 15$ & Equipment costs & $\mathrm{Pb} 37$ & Employee skills \\
\hline $\mathrm{Pb} 16$ & Tangle of yarn & $\mathrm{Pb} 38$ & Turn over \\
\hline Ps 17 & $\begin{array}{l}\text { Clean the remaining } \\
\text { oil }\end{array}$ & Ps 39 & Initial training \\
\hline Ps 18 & Thread tension settings & $\mathrm{Pb} 40$ & Not careful \\
\hline $\mathrm{Pb} 19$ & Changes often & $\mathrm{Pb} 41$ & Not following training \\
\hline $\mathrm{Pb} 20$ & Blunt needles & Ps 42 & Contrast color \\
\hline Ps 21 & $\begin{array}{l}\text { The new needle } \\
\text { checks income }\end{array}$ & $\mathrm{Pb} 43$ & Less attraction \\
\hline $\mathrm{Pb} 22$ & Difficulty checking & & \\
\hline
\end{tabular}
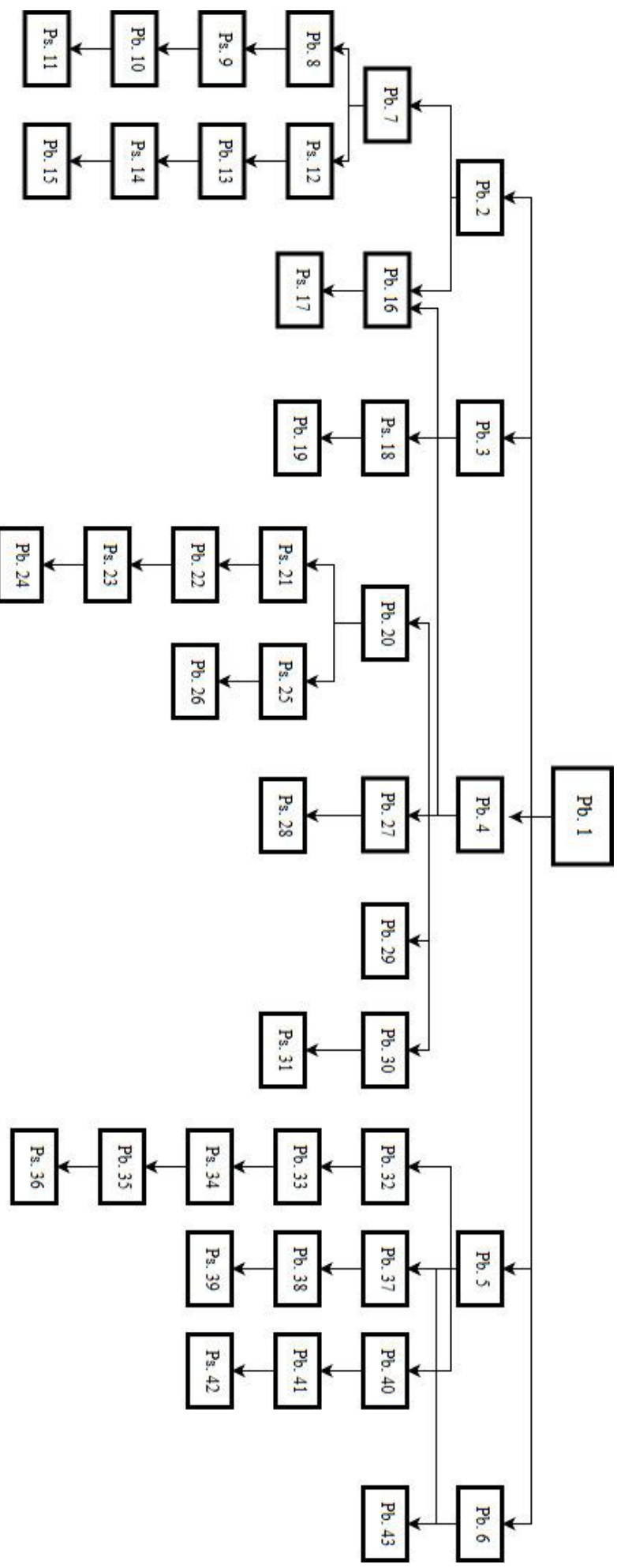

Figure 1. Chart NoP 
The $1^{\text {st }}$ International Conference on Business and Management of Technology (IConBMT)

TABLE 4.

FMEA FOR DEFECTS IN SEWING DEPARTMENT

\begin{tabular}{|c|c|c|c|c|c|c|c|c|}
\hline $\begin{array}{c}\text { Key Process } \\
\text { Input }\end{array}$ & \multicolumn{2}{|c|}{ Potential Failure Effect } & $S$ & Potential Causes & $O$ & Current Control & $D$ & $\mathrm{~S} \times \mathrm{O} \times \mathrm{D}=\mathrm{RPN}$ \\
\hline \multirow{14}{*}{$\begin{array}{l}\text { Departemen } \\
\text { Jahit }\end{array}$} & \multirow{3}{*}{$\begin{array}{l}\text { Needle } \\
\text { Fault }\end{array}$} & Thick material & 8 & The needle is stuck on the material & 6 & Decrease in speed & 2 & 96 \\
\hline & & Tangled thread & 9 & Remaining engine oil & 4 & Clean oil regularly & 6 & 216 \\
\hline & & Crooked needle & 9 & $\begin{array}{l}\text { Pressure buildup in the bent arch of } \\
\text { the needle }\end{array}$ & 7 & Check material income with aids & 5 & 315 \\
\hline & $\begin{array}{l}\text { Sagging } \\
\text { Seams }\end{array}$ & $\begin{array}{l}\text { Thread tension } \\
\text { settings }\end{array}$ & 6 & Settings often change & 7 & Perform periodic settings & 8 & 336 \\
\hline & \multirow{5}{*}{$\begin{array}{l}\text { Skip } \\
\text { stitches }\end{array}$} & \begin{tabular}{|l|} 
Blunt needle from \\
the supplier \\
\end{tabular} & 7 & Trouble checking & 2 & Check material income with aids & 5 & 70 \\
\hline & & \begin{tabular}{|l}
$\begin{array}{l}\text { Blunt needles } \\
\text { already used }\end{array}$ \\
\end{tabular} & 7 & $\begin{array}{l}\text { Continuous friction with the surface of } \\
\text { the material }\end{array}$ & 6 & Needle replacement & 6 & 252 \\
\hline & & Thick glue & 6 & Giving too much glue & 4 & Strict supervision of employees & 4 & 96 \\
\hline & & \begin{tabular}{|l} 
Upper lower \\
mechine settings
\end{tabular} & 7 & Settings often change & 3 & Perform periodic settings & 8 & 168 \\
\hline & & \begin{tabular}{|l|}
$\begin{array}{l}\text { Shuttle hock } \\
\text { napless }\end{array}$ \\
\end{tabular} & 8 & $\begin{array}{l}\text { Continuous friction with the surface of } \\
\text { the thread }\end{array}$ & 7 & $\begin{array}{l}\text { Rub the tip of the Shuttle hock } \\
\text { with sandpaper }\end{array}$ & 8 & 448 \\
\hline & \multirow{3}{*}{$\begin{array}{l}\text { Upper is not } \\
\text { symmetry }\end{array}$} & Target output & 8 & Productivity & 4 & Decrease in speed & 2 & 64 \\
\hline & & Employee skills & 8 & High employee turnover & 6 & Training new employees & 6 & 288 \\
\hline & & Less careful & 8 & Does not follow pattern marking & 5 & Change in marking color selection & 5 & 200 \\
\hline & \multirow{2}{*}{$\begin{array}{c}\text { Upper } \\
\text { wrinkled }\end{array}$} & Less attraction & 7 & Target output & 4 & Buffer storage & 5 & 140 \\
\hline & & Employee skills & 7 & High employee turnover & 6 & Training new employees & 6 & 252 \\
\hline
\end{tabular}

\section{Improve}

The TRIZ tool is used as a method to provide guidance on ideas for developing improvements to process improvements and NoP-FMEA is used to parse complex problems and determine the priority of problems based on their failure modes. In the improve phase, after identifying the existing matrix contradictions related to the parameters involved in each technical response, the causes of defects. Table 5 show the recommended improvement for each defect problem in the sewing department.

1) Principle 21 (Skipping)

Passing unnecessary processes. The process of turning the tension control wheel is the same as manually adjusting the zoom in/zoom out the lens. Often people want to zoom in on the object (zoom in) turning the lens ring to the left first. Even though it should rotate slowly to the right. This also happens when employees want to adjust thread tension. To pass the trial error activity, a direction marker is required.

\section{2) Principle 24 (Intermediary)}

Using an intermediary object or device, by making a tool for bending needle checks in the warehouse of material arrival. This tool is made of white cement / cast so it is lightweight at a low cost. The needle-shaped hole size has considered the tolerance agreed upon with the supplier. Arrival warehouse QC only needs to insert the needle into the tool hole, if the needle can enter and fit the size then the needle is said OK but if the needle cannot enter or is too loose the needle is said to be NG and returned to the supplier.

TABLE 5.

RECOMMENDATIONS FOR EACH TYPE OF DISABILITY

\begin{tabular}{|c|c|c|c|}
\hline $\begin{array}{l}\text { Defect } \\
\text { Type }\end{array}$ & $\begin{array}{l}\text { Principle } \\
\text { Inventive }\end{array}$ & Description & Recommendation \\
\hline \multirow[t]{2}{*}{$\begin{array}{l}\text { Skip } \\
\text { stitches }\end{array}$} & 10 & $\begin{array}{l}\text { Preliminary } \\
\text { Actiom }\end{array}$ & $\begin{array}{l}\text { Cleaning and checking the } \\
\text { position of the shuttle } \\
\text { hock end of each shift }\end{array}$ \\
\hline & 10 & $\begin{array}{l}\text { Preliminary } \\
\text { Actiom }\end{array}$ & $\begin{array}{l}\text { Check the tip of the } \\
\text { needle is still sharp or } \\
\text { blunt every } 2 \text { shifts }\end{array}$ \\
\hline $\begin{array}{l}\text { Sagging } \\
\text { Seams }\end{array}$ & 21 & Skipping & $\begin{array}{lrr}\begin{array}{l}\text { Giving } \\
\text { stickers }\end{array} & \text { near } & \text { direction } \\
\text { regulator } & & \end{array}$ \\
\hline $\begin{array}{l}\text { Needle } \\
\text { Fault }\end{array}$ & 24 & Intermediary & $\begin{array}{l}\text { Tools for bending needle } \\
\text { checks }\end{array}$ \\
\hline \multirow{4}{*}{$\begin{array}{l}\text { Upper is } \\
\text { not } \\
\text { symmetry }\end{array}$} & 24 & Intermediary & $\begin{array}{l}\text { Upper symmetry checking } \\
\text { tools }\end{array}$ \\
\hline & 10 & $\begin{array}{l}\text { Preliminary } \\
\text { Actiom }\end{array}$ & $\begin{array}{l}\text { Initial training of new } \\
\text { employees }\end{array}$ \\
\hline & 1 & Segmentasi & $\begin{array}{l}\text { Making employee } \\
\text { mapping skills }\end{array}$ \\
\hline & 32 & $\begin{array}{l}\text { Color } \\
\text { change }\end{array}$ & $\begin{array}{l}\text { Use of striking colors for } \\
\text { marking patterns }\end{array}$ \\
\hline \multirow[t]{2}{*}{$\begin{array}{l}\text { Upper } \\
\text { wrinkled }\end{array}$} & 10 & $\begin{array}{l}\text { Preliminary } \\
\text { Actiom }\end{array}$ & $\begin{array}{l}\text { Initial training of new } \\
\text { employees }\end{array}$ \\
\hline & 1 & Segmentasi & $\begin{array}{l}\text { Making employee } \\
\text { mapping skills }\end{array}$ \\
\hline
\end{tabular}




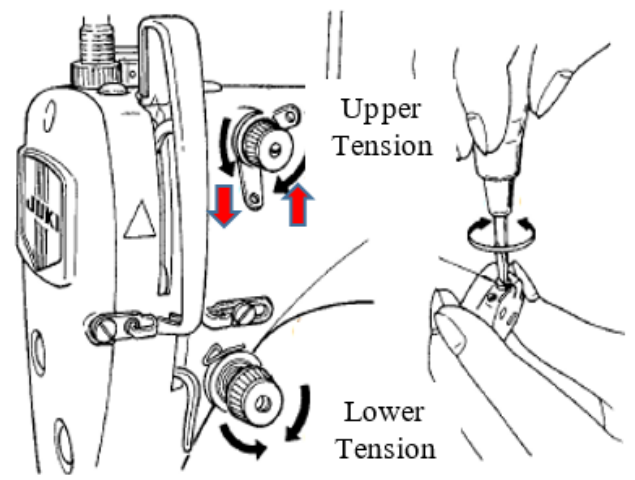

Figure 2. Giving Sticker

\section{3) Principle 24 (Intermediary)}

Using an intermediary object or device, by making a tool for bending needle checks in the warehouse of material arrival. This tool is made of white cement / cast so it is lightweight at a low cost. The needle-shaped hole size has considered the tolerance agreed upon with the supplier. Arrival warehouse QC only needs to insert the needle into the tool hole, if the needle can enter and fit the size then the needle is said OK but if the needle cannot enter or is too loose the needle is said to be NG and returned to the supplier.

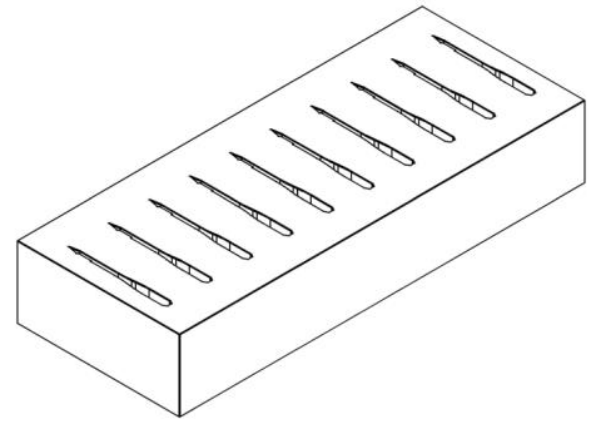

Figure 3. Crooked Needle Check Tool.

\section{4) Principle 24 (Intermediary)}

Using an intermediate object or device by making Upper symmetry checking tools at the end of the sewing line. This tool is made of wood / plywood so it is lightweight at a low cost. The size of the curve is adjusted to the size of the shoe that is being processed in the production line. During this time QC production only saw visually whether the product that was made was symmetrical or not. This makes the QC often wrong in the checking process so that the defect product continues to flow to the next department. By using this tool besides being able to accurately see symmetrical shoe products, this tool will also speed up the checking process. QC only needs to see signs of cutting the front and back of the Upper whether touching the iron stick of the tool. If it touches then the product is OK, but if it does not touch the front or back, it means the NG product. 5) Principle 1 (Segmentasi)

Dividing objects into independent parts, by mapping employee skills (mapping skills). Skill mapping is by giving an identity to each employee in the sewing department about what abilities are mastered and which are not mastered. It aims to make it easier for companies to rotate and re-recruit employees who have been fired according to the skills needed. Skill mapping is the company's consideration in recruiting, breaking contracts, and making training.

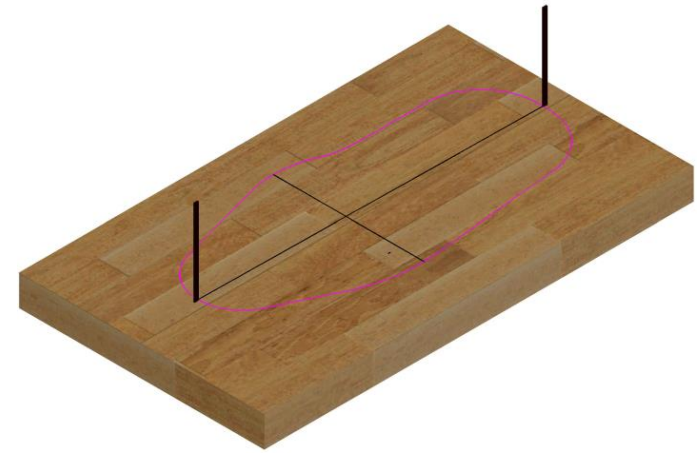

Figure 4. Symmetry Check Tool

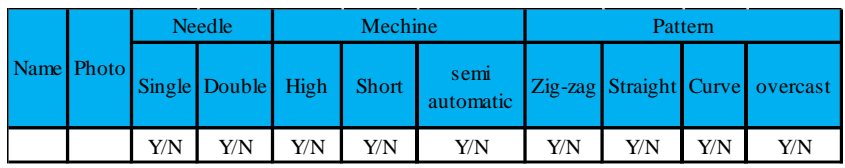

6) Principle 32 (Color change)

To provide a pattern that is easily seen by employees, the color of the pattern must use striking colors and contrast with the Upper color base. Therefore, the researcher gave a proposal to use glow in the dark paint or phosphor paint with waterbased types which included acrylic glow in the dark paint, usually used for media that is porous and can absorb water such as cloth, paper, canvas, walls, wood that has not been lacquered and so on.

\section{Estimated Defect Reduction After Repair}

From the recommendations given based on 40 inventive principles, the following Table 6 shows estimates of defect reduction:

TABLE 6 .

ESTIMATED REDUCTION DEFECT

\begin{tabular}{lccc}
\hline \hline Defect Type & $\begin{array}{c}\text { Initial } \\
\text { Defect }\end{array}$ & $\begin{array}{c}\text { \% } \\
\text { Reduction }\end{array}$ & $\begin{array}{c}\text { Estimated Final } \\
\text { Defect }\end{array}$ \\
\hline Skip stitches & 563 & $20 \%$ & 338 \\
Sagging Seams & 502 & $10 \%$ & \\
Needle Fault & 362 & $30 \%$ & 452 \\
Upper is not & 301 & $5 \%$ & 253 \\
symmetry & & $20 \%$ & 120 \\
& & $15 \%$ & \\
& & $20 \%$ & \\
Upper wrinkled & 281 & $25 \%$ & 141 \\
\multicolumn{1}{c}{ Total } & 2009 & $25 \%$ & \\
\hline \hline
\end{tabular}


The $1^{\text {st }}$ International Conference on Business and Management of Technology (IConBMT)

August 3rd 2019, Institut Teknologi Sepuluh Nopember, Surabaya, Indonesia

TABLE 7.

SigMA LEVELS AND CAPABILITY PROCESS

\begin{tabular}{lcccc}
\hline \hline Characteristics & Total Defect & \% Defect & Level Sigma & Cp \\
\hline Existing Conditions & 2009 & $2 \%$ & 4.1 & 0.89 \\
Target & 1000 & $1 \%$ & 4.4 & 1 \\
After Improvement & 1304 & $1.3 \%$ & 4.3 & 0.93 \\
\hline \hline
\end{tabular}

Table 7 shows that after implementing recommendations for improvement, the estimated defect reduction is 705 pairs of shoes. Estimated reduction in defect percentage by $0.7 \%$. Sigma levels rose 0.2 compared to before. Process capability increased 0.04 compared to existing conditions. Even though it still does not meet the target of the company, it defects $1 \%$ of total production, but the defect reduction after repairs is sufficiently experienced a significant reduction. To be able to achieve the company's target, the effort that must be made is to continue to maintain consistency in what has been improved and continuously make improvements both on the production floor and product design.

\section{CONCLUSION}

Based on the research described earlier, we can conclude as follows:

a. By integrating OTSM-TRIZ and FMEA it is proven that it can reduce the number of defects in the sewing department by 705 pairs of shoes.

b. Integration of OTSM-TRIZ and FMEA can be applied in complex interconnected problems. The solutions that are generated are expected to be more resilient to the potential for failure.

c. Further research is very open to modeling sub-problem $(\mathrm{Pb})$ weighting when integrating with FMEA.

\section{REFERENS}

[1] P. B. Crosby, Quality is Free. New York: McGraw-Hill, 1979.

[2] W. E. Deming, Out of the Crisis: Quality, Productivity, and Competitive Position. Cambridge, Massachusetts: Cambridge University Press, 1982.

[3] A. V. Feigenbaum, Total Quality Service. Singapore: Mc Graw Hill Book Co., 1986.
[4] D. A. Garvin, Managing Quality: The Strategic and Competitive Edge. New York: Free Press, 1988.

[5] J. M. Juran and F. M. Gryna, Quality Planning and Analysis. New York: Graw Hill Book, 1993.

[6] M. L. Singgih and R. Renanda, "Peningkatan kualitas produk kertas dengan menggunakan pendekatan six sigma di pabrik kertas Y,” in Seminar Nasional Teknologi Simulasi IV, 2008.

[7] G. J. Hahn, W. J. Hill, R. W. Hoerl, and S. A. Zinkgraf, "The impact of six sigma improvement - a glimpse into the future of statistics," Am. Stat., vol. 53, no. 3, pp. 208-215, 1999.

[8] A. Czinki and C. Hentschel, "Solving complex problems and TRIZ," in Procedia CIRP - TRIZ Future Conference 2015, 2016, vol. 39, pp. 27-32.

[9] G. S. Al'tsuller, The Innovation Algorithm: TRIZ, Systematic Innovation and Technical Creativity. Worcester, MA: Technical Innovation Center, 1999.

[10] H. Yu, D. Fan, and Y. Zhang, "The research of improving the particleboard glue dosing process based on TRIZ analysis," in IFIP Advances in Information and Communication Technology, 2009, vol. 304, pp. 97-107.

[11] K. Gadd, TRIZ for Engineers: Enabling Inventive Problem Solving. Chichester, Canada: John Wiley \& Sons, Ltd, 2011.

[12] P. F. Bariani, G. A. Berti, and G. Lucchetta, "A Combined DFMA and TRIZ approach to the simplification of product structure," Proc. Inst. Mech. Eng. Part B J. Eng. Manuf., vol. 218, no. 8, pp. 1023-1027, 2004.

[13] W.-C. C. J.L. Chen, "TRIZ based eco-innovation in design for active disassembly," Pap. Present. 14th CIRP Conf. Life Cycle Eng., 2007.

[14] H. K. H. Yamashina, T. Ito, "Innovative product development process by integrating QFD and TRIZ," Int. J. Prod. Res. 40 1031-1050, 2002

[15] T. Sakao, "A QFD-centred design methodology for environmentally conscious product design," Int. J. Prod. Res. 45 4143-4162, 2007.

[16] H. Wang, G. Chen, Z. Lin, and H. Wang, "Algorithm of integrating QFD and TRIZ for the innovative design process," Int. J. Comput. Appl. Technol., vol. 23, no. 1, pp. 41-52, 2005.

[17] H. Kobayashi, "A systematic approach to eco-innovative product design based on life cycle planning," Adv. Eng. Informatics, vol. 20, no. 2, pp. 113-125, 2006

[18] L. Frizziero and F. R. Curbastro, "Innovative methodologies in mechanical design: QFD vs TRIZ to develop an innovative pressure control system," ARPN J. Eng. Appl. Sci., vol. 9, no. 6, pp. 966-970, 2014.

[19] S. Rafsanjani, "Pengendalian dan Perbaikan Kualitas Proses Printing Kemasan Produk Menggunakan Integrasi FMEATRIZ,” Institut Teknologi Sepuluh Nopember, 2018.

[20] L. Fiorineschi, F. S. Frillici, and P. Rissone, "A comparison of Classical TRIZ and OTSM-TRIZ in dealing with complex problems," Procedia Eng., vol. 131, pp. 86-94, 2015. 